Saeculum Christianum

t. XXVII $\cdot 2 / 2020$

s. $60-73$

\author{
KRZYSZTOF RATAJCZAK ${ }^{1}$ \\ Uniwersytet im. Adama Mickiewicza w Poznaniu \\ ORCID: 0000-0002-1298-986X
}

\title{
THE SCHOOL LEGISLATION OF THE CATHOLIC CHURCH IN THE HUSSITE TIMES
}

\begin{abstract}
The aim of the paper is to show the state and changes in the school legislation of the Catholic Church in the crucial period of its history, between 1378 and 1477. The focus of the analysis is especially on the acts of law decreed by the popes, on the canons of the councils, but also on the ius particulare of those ecclesiastical provinces that were affected by the Hussite movement. Also, factors influencing the ecclesiastical law in the realm of education are analysed, such as political, social, economic besides religious. Very important was the question if the changes could be controlled or inspired by the Church or whether the changes of the school legislation were only meant to preserve the status quo.
\end{abstract}

Keywords: School legislation of the Catholic Church, Middle Ages, Hussite period

\section{Streszczenie}

Celem artykułu jest ukazanie stanu szkolnego ustawodawstwa Kościoła Katolickiego i jego przemian w kluczowym dla historii Kościoła okresie pomiędzy 1378 a 1477 r. Przedmiotem analizy są zwłaszcza akty prawne ustanowione przez papieży, kanony soborowe, ale także ius particulare tych prowincji kościelnych, które zostały dotknięte przez ruch husycki. Dokonano także analizy czynników politycznych, społecznych, ekonomicznych, ale także religijnych, które wpłynęły na ustawodawstwo kościelne w sferze edukacji. Bardzo ważną kwestią jest odpowiedź na pytanie, czy owe przemiany mogły być kontrolowane, czy inspirowane przez Kościół, czy też zmiany szkolnego ustawodawstwa były jedynie próbą status quo?

Słowa kluczowe: szkolne ustawodawstwo Kościoła Katolickiego, średniowiecze, epoka husycka

\footnotetext{
1 Krzysztof Ratajczak, profesor w Zakładzie Historii Wychowania Uniwersytetu im. Adama Mickiewicza w Poznaniu. Specjalizuje się w dziejach edukacji i kultury w wiekach średnich. Autor książek i artykułów poświęconych m.in. średniowiecznemu szkolnictwu, kulturze rycerskiej, zakonom rycerskim, krucjatom, edukacji kobiet oraz zakonowi cysterek. E-mail: krzysztof.ratajczak@amu.edu.pl.
} 
$\mathrm{A}_{\mathrm{i}}^{\mathrm{t}}$ $\mathrm{t}$ the beginning of my paper I would like to make a brief summary of the origins and most important periods in the history of ecclesiastical legislation in the realm of education. In the first period - between the $6^{\text {th }}$ and $9^{\text {th }}$ centuries - we observe that the Church had to solve problems concerning both the situation of ancient, Roman schools, and the education of the clergy. ${ }^{2}$ Canons of the synod in Toledo of 633, led by St. Isidor of Sevilla, formulated the program of clergy's education. They were made to study the Bible, Psalms etc., for further teaching. ${ }^{3}$

Until the Carolingian period, some of the monasteries accepted both boys and girls as pupils in their schools. In 787 Charlemagne issued a capitulary to all abbots and bishops of Frankland, urging them to promote studies and teaching in their communities. ${ }^{4}$ The capitularies of 789 and 802 ordered establishing a school for boys in every monastery and episcopal church, where they would be taught reading, singing, arithmetic, and grammar. ${ }^{5}$ Also, Theodulf, Bishop of Orleans decreed a plea of free elementary education for the poorest. ${ }^{6}$ During the reign of Louis the Pious, a law was passed in 817, ordering each monastery to run an internal school, schola interior, and an external school, schola exterior. Cathedral schools, too, had internal and external branches (exemplary school in Rheims). ${ }^{7}$ During the ninth century many bishops followed the example of Theodulf of Orleans and charged the clergy to open schools in their parishes. ${ }^{8}$ We can find the spirit of Carolingian educational law in the collection of canon law that was prepared before the Gregorian reform. ${ }^{9}$

The second period was marked by the Gregorian reform and by the development of the canonical collections. ${ }^{10}$ In that period we can find a variety of important decisions concerning education in a papal bull and other forms of documents, e.g. in 1231 Pope Gregory IX allowed studying Aristoteles's book Physica in Paris. ${ }^{11}$ The Decrees of Gregory IX of 1234 contain an article which states that running parochial schools is mandatory. ${ }^{12}$ Popes were interested especially in establishing and running universities. We know plenty of papal bulls issued for European universities.

\footnotetext{
2 P. Riché, Edukacja i kultura w Europie Zachodniej (VI-VIII w.), transl. M. Radożycka-Paoletti, Warszawa 1995, p. $109,138$.

H. Mordek, Kirchenrecht und reform im Frankenreich. Die Collectio vetus Gallica. Die Älteste systematische kanonessammlung des Fränkischen Gallien. Studien und edition, Berlin-New York 1975, p. 378, 513.

4 Monumenta Germaniae Historica (futher: MGH), Leges, sectio II, Capitularia regum Francorum, Bd. 1, ed. A. Boretius, Hannoverae 1883, p. 79.

5 Patrologia Latina (further: PL), XCVII, p. 517; MGH, Capitularia regum Francorum, Bd. 1, pp. 56-62. Capitulary from 802: Capitularia regum Francorum, Bd. 1, p. 235.

$6 \quad P L$, CV, p. 196, MGH, Leges II, Capitularia, Bd. 1, pp. 115-116.

7 P.J. McCormick, History of Education, Chicago 1957, pp. 230-231.

8 J. Johnson, A Collection of the Laws and Canons of the Church in England, vol. 1, Oxford 1850, Concilium Parisense a. 829, Cap. XXX, in: MGH, Concilia aevi Karolini, ed. A. Werminghoff, Bd. 2, Hannoverae-Lipsiae 1906, p. 632; Hinkmar of Reims, PL, CXXV, canon 11, col. 778.

9 Collectio canonum in V libris (lib. I-III), ed. M. Fornasari, Turnholti 1970, p. 81.

10 Ch. Rolker, Canon Law and the Letters of Ivo of Chartes, New York 2010; G. Austtin, Shaping Church Law Around the Year 1000. The Decretum of Burchard of Worms, Farnham-Burlington 2009; The History of Medieval Canon Law in the Classical Period, 1140-1234: From Gratian to the Decretals of Pope Gregory IX, ed. W. Hartmann, K. Pennington, Washington 2008.

11 J. Sarnowsky, Die artes im Lehrplan der Universitäten, in: Artes im Mittelalter, hrsg. v. U. Schaefer, Berlin 1999, p. 68-82, here: p. 69.

12 Corpus Juris Canonici, ed. E. Friedberg, Bd. 2, Leipzig 1881, kol. 449, Decretum III, tit.1, cap. III.
} 
The most important period in the development of educational legislation was the second half of the $12^{\text {th }}$ century, and the next century, which actually was the golden era of monasticism and schools. The Third Council of the Lateran, held in 1179, decreed that free schools should be reopened in those churches and monasteries, where formerly existed funds for this purpose. ${ }^{13}$ Another important question mentioned by the Council was the law of licentia docendi connected with organisation of universities. ${ }^{14}$ All the statutes of the Third Lateran Council of 1179 were published in Liber extra, collection of the canon law prepared by Rajmundus de Peñafort in 1234 and promulgated by Pope Gregory IX to use in iudiciis et in scholis.

The Fourth Council of the Lateran, held in 1215, renewed decrees on schools. In canon XI, De magistris scholasticis, the Council ordered to employ theology teachers in each cathedral school, and also to provide funding to open new schools wherever possible. ${ }^{15}$ Parish churches should maintain a teacher of grammar who would give boys elementary education, thus enabling them to take up further studies in a cathedral or collegiate school. ${ }^{16}$

As mentioned, the $13^{\text {th }}$ century was the golden age of monasticism and schools. New, centralised orders, such as the Cistercians, Franciscans and Dominicans, established an impressive network of schools. Almost every year the general chapter of the Dominicans decreed new articles thoroughly describing the organisation of convent schools and the network of more specialised schools, which, over the years, were updated and improved. ${ }^{17}$ A similar law was decreed by the general chapters of the Cistercians and Franciscans. ${ }^{18}$ There was a tendency to establish convent school in every single monastery, schools of art in the biggest convents, and general schools - in the universities..$^{19}$ During the $13^{\text {th }}$ century, the Cistercians started to organize, like the Dominicans, a system of convent schools, depending on the number of monks in a convent ${ }^{20}$. Obligatory studies for Cistercians were

13 Dokumenty soborów powszechnych (further: DSP), v. II: (869-1312), ed. A. Baron, H. Pietras, Kraków 2002, p. 170.

14 A.B. Cobban, The Medieval Universities. Their Development and Organization, Oxford 1975, passim; H. Rashdall, The Universities of Europe in the Middle Ages, vol. 2, part 1: Italy, Spain, France, Germany, Scotland etc., Cambridge 2010.

15 DSP, II, p. 246.

16 A.J. Duggan, Conciliar Law 1123-1215. The Legislation of the Four Lateran Councils, in: The History of Medieval Canon Law, pp. 318-366.

17 Acta capitulorum generalium Ordinis Praedicatorum, vol. 1: Ab anno 1220 usque ad annum 1303, ed. A. Frühwirth, B.M. Reichert, Romae 1898, passim. M.M. Mulchahey, "First the Bow is Bent in Study..." Dominican Education before 1350, Toronto 1998; L.E. Boyle, Notes on the Education of the "Fratres communes" in the Dominican Order in the Thirteenth Century, in: Xenia medii aevi historiam illustrantia oblata Thomae Kaeppeli, ed. R. Creytens, P. Künzle, vol. 1, Roma 1978; W.A. Hinnebusch OP, The History of the Dominican Order. Intellectual and Cultural Life to 1500, vol. 1-2, New York 1973; K. Kaczmarek, Szkoły i studia polskich dominikanów w okresie średniowiecza, Poznań 2005; M. Zdanek, Szkoły i studia dominikanów krakowskich w średniowieczu, Warszawa 2005; J. Kłoczowski, Polska Prowincja Dominikańska w średniowieczu i Rzeczypospolitej Obojga (wielu) Narodów, Poznań 2008.

18 B. Roest, A history of Franciscan Education (c.1210-1517), Leiden-Boston-Köln 2000; I. Eberl, Cystersi. Historia zakonu europejskiego, transl. P. Włodyga, Kraków 2011, p. 196-267; K. Stopka, Szkoła zakonna w Polsce średniowiecznej jako problem badawczy, in: Klasztor $w$ kulturze średniowiecznej Polski, ed. A. Pobóg-Lenartowicz, M. Derwich, Opole 1995, p. 49-61.

19 Statuta capitulorum generalium, passim. K. Kaczmarek, Studia uniwersyteckie cystersów z ziem polskich w okresie średniowiecza, Poznań 2002, pp. 27 ff.

20 Statuta capitulorum generalium, vol. 3, p. 207, 238. 
ordered by Pope Benedict XII in 1335 in the bull Fulgens sicut stella. ${ }^{21}$ Similar regulations were prescribed for the Franciscans (Redemptor noster, 1336), ${ }^{22}$ the Canons Regular of St. Augustine (Ad decorem Ecclesiae 1339), ${ }^{23}$ and the order of St. Benedict (Summa magistri, or Benedictina 1336). ${ }^{24}$

In the late medieval period, the number of schools grew rapidly, which was closely connected with the social developments and the creation of towns. In the $14^{\text {th }}$ and $15^{\text {th }}$ centuries some private elementary schools were run by wandering clergy (scholares vagantes, called also bacchantes). Former university students or teachers in town schools moved from place to place and gathered small boys whom they instructed. ${ }^{25}$ In Silesian towns, mainly in Wrocław, there were independent teachers, who did not seek permission or cooperation with parochial schools. ${ }^{26}$ In the Netherlands a new form of education appeared. The Brethren of the Common Life was an association of priests and laymen founded by Gerard Groote (1340-1384) at Deventer. Its members lived in a community and chose teaching as one of their main duties. They ran elementary and secondary schools. ${ }^{27}$

Such changes motivated the Church to rewrite some older norms concerning education. Pope John XXII urged the orders to pay attention to the employment of appropriate teachers in convent schools. ${ }^{28}$ During the Council of Basel (1431-1445) the Church tried to achieve a higher level of education, especially among the clergy. ${ }^{29}$ Its decree states also that Jewish teachers cannot work in schools. ${ }^{30}$

The development of education, wherever it took place, was part of a much wider transformation of society. As Collin Morris states, social and economic circumstances were the "cause" while the new education - the "effect," for the skills acquired through better education were important in altering the living conditions of the society. ${ }^{31}$ The economic development of cities during the late Middle Ages enabled local communities to take over the patronage of parochial schools from the Church. The process was visible in the late $14^{\text {th }}$ century in Germany as well as in Silesia, Bohemia, and the Kingdom of Poland. ${ }^{32}$

It was believed during the Middle Ages that the number of educated people in Bohemia was the highest in Europe. Since there were shortage of possibilities to study in Prague, students from Bohemia moved to France and England. In 1451 Aeneas Silvius Piccolomini,

\footnotetext{
21 Benedict XII, Fulgens sicut stella, in: Bullarium diplomatum et privilegiorum sanctorum romanorum pontificium, ed. A. Tomasseti, vol. 4, Roma 1859, pp. 329-345, Statuta capitulorum generalium, vol. 3, Lovanium 1935 , pp. 410-436.

22 Redemptor noster, in: Bullarium diplomatum et privilegiorum, pp. 391-415.

23 Ad decorum Ecclessiae, in: ibidem, p. $425 \mathrm{ff}$.

24 Benedict XII, Summi Magistri dignatio nos, in: ibidem, pp. 347-387.

25 P.J. McCormick, History of Education, p. 311.

26 K. Maleczyńska, Zainteresowania czytelnicze mieszczan dolnoślaskich okresu Renesansu, Wrocław 1982, p. 24.

27 T.P. Van Zijl, Gerard Groote, ascetic and reformer (1340-1384), Washington 1963.

28 Decree 14. 14, in: ibidem, p. 566.

29 DSP, III, p. 320.

30 Ibidem, p. 347.

31 C. Morris, The Discovery of the Individual 1050-1200, Toronto 1991, p. 37.

32 M. Kintzinger, Stadt und Schule im hoch- und spätmittelalterlichen Reich. Genese und Perspektiven der mediävistlichen Stadtschulforschung, in: Schullandschaften in Altbayern, Franken und Schwaben. Untersuchungen zur Ausbreitung und Typologie des Bildungswesens im Spätmittelalter und Früher Neuzeit, hrsg. v. H. Flachenecker, R. Kiessling, München 2005, p. 23 ff.
} 
the later Pope Pius II, visited Prague. He praised the level of education of the people of the country, suggesting that "in Bohemia every old woman knows the Holy Scriptures better than certain prelates in Rome". ${ }^{33}$ The University of Prague was a place where the social and religious thoughts of John Wyclif were well known and discussed. In 1411, Archbishop Arundel ordered a visit to the university to detect Wyclif's circles. The university authorities tried to defend their autonomy before the king and parliament - but they lost the case. ${ }^{34}$

$$
* * *
$$

The Hussite Revolution began on 31 June 1419 and the death of King Václav IV on 16 July 1419 made it easier for the Hussites to seize power in Prague and for Hussite ideology to spread quickly in Bohemia. The Hussite movement is famous for its emphasis on equality and for its demands that the Bible should be available in vernacular (at the time when all Masses were in Latin) and that everyone should be educated to read and understand the Word, which addressed both men and women. Their ideals of equality attracted an enormous number of people, without a radical separation of the two genders. Since the Hussite period has always been considered one of most important in the Czech history, the necessity of educating both genders was taken for granted and perceived as vital for the benefit of the nation. ${ }^{35}$

In January 1420, in connection with the Hussite issue, the Reichstag was held in Wrocław, and its decisions concerned Polish affairs to some extent, too. ${ }^{36}$ They were a response to the Four Articles of Prague of 1420, which allowed the free proclamation of the word of God, while rejecting the licentia praedicatori, - permitted holy communion for lay people under two kinds, recommended poverty to the clergy, and allowed punishment for cardinal sins by secular authorities. ${ }^{37}$

The Hussite synods testified that the authority of the Bible and the oldest Church tradition were still at the centre of the faith. While their decrees concentrated mainly on the Eucharist, on liturgy and dogmas, they also raised financial issues and presented suggestions concerning prevailing problems in the society. ${ }^{38}$ Several articles concerned schools, such as article 25 of the synod of Prague in 1434: De promotione cuiusque scholae et studii. ${ }^{39}$

The number of parishes increased significantly in Central Europe during the studied period. ${ }^{40}$ In the middle of the 14th century, the Archbishopric of Prague had 1914 parishes,

\footnotetext{
33 Aenae Silvii Historia Bohemica - Enea Silvio Historie Česká, ed. D. Martínkova, A. Hadravová, J. Matl, Praha 1998.

34 B. Topfer, Rola uniwersytetów oksfordzkiego i praskiego w rozwoju koncepcji wczesnoreformacyjnych (koniec XIV-poczatek XV wieku), „Kwartalnik Historyczny” 89 (1982), v. 1, p. 7.

35 F. Šmahel, Husitská revoluce, vol. 3: Kronika válečných let, Praha 1993; P. Čornej, Svétla a stíny husitství (události-osobnosti - texty - traduce). Výbor z úvah a studii, Praha 2011.

36 J. Nikodem, Polska i Litwa wobec husyckich Czech w latach 1420-1433. Studium o polityce dynastycznej Władysława Jagietty i Witolda Kiejstutowicza, Poznań 2004.

37 S. Bylina, Podróż husytów do Bazylei, Warszawa 2013, p. 13.

38 B. Zilynská, Husitské synody v Čechách, 1418-1440. Př́spěvek k uloze univerzitních mistrů v husitské cirkvi a revoluci, Praha 1985, p. 102-107.

39 Ibidem, p. 123.

40 Pfarrein im Mittelalter, Deutschland, Polen, Tschechen und Ungarn im Vergleich, hrsg. N. Kruppa, Göttingen 2008, passim.
} 
while at the outset of the Hussite Revolution their number increased to $2084 .^{41}$ This process was also accompanied by a significant expansion of a school network, and the increase of the number of teachers and pupils. ${ }^{42}$ The situation was similar in the Diocese of Cracow, where the majority of the total number of about 900 parishes was established in the 15th century. ${ }^{43}$ A school network was well developed there, too. ${ }^{44}$ The number of parish schools in Lesser Poland was not inferior to that of parish schools in Greater Poland ${ }^{45}$ It is worth noting that the situation in late medieval Bohemia and Poland did not differ in this respect from that in Germany at the time. ${ }^{46}$

In the Diocese of Prague, an average parish covered $28 \mathrm{~km}^{2}$. In Prague alone there were 28 schools. Interestingly, about $25-30 \%$ of the students who graduated in Prague during 1399-1418 came from villages where there were no schools in the strict sense of the word. ${ }^{47}$ This means that at that time many children in the Czech lands received basic literacy as part of their family or religious education. It is important to note that the Czech written culture was rather highly secularized and democratic, especially because of the great accessibility to it by broad social masses. ${ }^{48}$ Undoubtedly, the increased access to education was made possible for peasant children thanks to the activities of the clergy - priests themselves taught groups of boys without employing additional teachers. ${ }^{49}$

The rapid rise in the number of schools, pupils, and teachers, often without the necessary skills was a problem which had to be solved by law. Both a growing population of scholares and lack of well-prepared teachers posed a problem. For graduates teaching was not attractive because of a relatively low salary, so the role of a teacher was played mainly by university students. ${ }^{50}$ As to the population at schools, sources suggest that the average number of pupils was not really big, oscillating between 5-15 in small towns and villages, whereas in

41 E. Doležalová, Z. Hledíková, Die Erforschung der Entstehung und Ausprängung des Pfarreinetzes bis zum Beginn der hussitischen Revolution in der tschechischen Geschichtswissenschaft, in: Pfarrein im Mittelalter, p. 88.

42 B.M. Nodl, Klerici, rektoři a scholárové, in: Pater familia. Sbornik přispěvků kživotnimu jubileu Prof. Dr. Ivana Hlaváčka, ed. J. Hrdina, Praha 2002, p. 299-311; F. Šmahel, Causa non grata: Premature Reformation in Hussite Bohemia, in: Christianity in East Central Europe. Late Middle Ages. Proceedings of the Comission Interlationale d'Histoire Ecclésiastique Comparée, Lublin 1996, part 2, ed. J. Kłoczowski, P. Kras, W. Polak, Lublin 1999 , p. 232.

43 Jan Długosz, Liber Beneficiorum Diocesis Cracoviensis, vol. 1-3, ed. A. Przeździecki, Kraków 1863-1864. P. Plisiecki, The Parochial Network and the Tithes System in the Medieval Diocese Cracow, in: Pfarrein im Mittelalter, p. 223-234.

44 E. Wiśniowski, Uwagi o liczebności wiejskiego szkolnictwa parafialnego w Polsce $i$ w Czechach u schyłku średniowiecza, in: Kultura elitarna a kultura masowa w Polsce późnego średniowiecza, ed. B. Geremek, Wrocław 1978, p. 207-210.

45 K. Ratajczak, Szkolnictwo w Wielkopolsce na tle sąsiadów w okresie średniowiecza, Poznań 2017, passim.

46 R. Jakob, Spätmittelalterliche Schullandschaften in Franken und in Bayern 1250-1520. Ein Vergleich anhand ausgewählter Perspektiven und Beispiele, in: Schullandschaften in Altbayern, Franken und Schwaben, p. 157-182.

47 F. Šmahel, Stowo pisane i mówione w stużbie reformy husyckiej, transl. P. Kras, in: Kultura pisma w średniowieczu. Znane problemy, nowe metody, ed. A. Adamska, P. Kras, Lublin 2013, p. 179.

48 F. Šmahel, Piśmienność warstw ludowych w Czechach w XIV i XV wieku, in: Kultura elitarna a kultura masowa w Polsce późnego średniowiecza, ed. B. Geremek, Wrocław 1978, p. 189.

49 Ibidem, p. 196-197.

50 M. Kitzinger, Studens atrium, Rector parochie und Magister scolarum im Reich des 15. Jahrhunderts. Studium und Versorgunschancen der Artisten zwischen Kirche und Gesellschaft, „Zeitschrift für Historische Forschung“, 26(1999), p. 1-43; idem, A profession but not a Career? Schoolmasters and the Artes in Late Medieval Europe, in: Universities and schooling in Medieval Society, ed. W.J. Courtenay, J. Miethke, Leiden-Boston-Köln 2000, p. 167-181 . 
the cities, of course, schools were bigger. ${ }^{51}$ The real problem was the migration of pupils completely out of control.

Such issues made bishops prepare appropriate changes in the diocesan law. In the statutes of the Archdiocese of Prague, the first article on schools appeared in $1390 .{ }^{52}$ Its goal was to purge the schools of suspected students and teachers. ${ }^{53}$ Another question appeared in the statues of the synod of 1408: the use of heretic books was forbidden. ${ }^{54}$ The same problem was approached by the synod of $1410 . .^{55}$ The Church supported the activities of municipal schools while banning the establishing of rural schools. In 1412, the Moravian synod of Vyškov prohibited increasing the number of village schools due to the lack of experienced rectors, to laziness, and various offences committed by schoolboys. ${ }^{56}$ This attitude of the Church authorities resulted in the fact that, in the 14th and 15th centuries, the Czech education was still available to just a relatively small group of students. Their number usually did not exceed 20-50 people in town schools, whereas in the countryside it was even lower. One alternative to Church schools were bourgeois schools run in Czech or German. In the 15th century, the Hussites themselves strived to establish schools of an institutional character. They have also managed to shift responsibility for the care of schools to city councils or secular church property administrators in parishes. ${ }^{57}$ This situation was very similar to what it looked like in Germany, where in the 14th century towns took over the responsibility for running schools from the Church. ${ }^{58}$.

In the diocese of Olomouc, the statutes decreed in 1349 by bishop John VII Volek ordered that the teachers at schools should be Czech, a regulation similar to the statutes of Łęczyca issued in 1285, which defended the Polish language. ${ }^{59}$ In the statutes of 1413, article 32 (De eleccione rectoris scolarium), described the conditions of choosing a right teacher in similar ways. The next article showed the concern of the Church for the increasing number of schools, especially in villages, which multa mala comittuntur because of the lack of welleducated teachers. ${ }^{60}$

Intellectual changes were possible because of the rapid rise in the number of books, written also in vulgari. It was an important aspect, since books became available also for women, and the reaction of the Church was visible in the act of the synod of Elblag, 1427. The synodal sermon warns that there is a danger of mistakes in the faith caused by women's reading theological texts translated from Latin into German. ${ }^{61}$ And after Hus's condemnation at Constance, the Polish clergy took steps to stop the penetration of Hussite ideas by means

\footnotetext{
${ }^{51}$ F. Heiler, Schulen in der Kleiner hochstiftsstädten. Ein Vergleich innerhalb des Hochstifts Erchstädt und mit seinen weltlichen Nachborn (ca. 1400-1600), in: Schullandschaften in Altbayern, Franken und Schwaben, p. 62-74.

52 Pražské synody a koncily předhusitské doby, ed. J.V. Polc, Z. Hledíková, Praha 2002, p. 252.

53 Ibidem, p. 254.

54 Ibidem, p. 288.

55 Ibidem, p. 291.

56 Ibidem, p. 195.

57 F. Šmahel, Piśmienność warstw ludowych w Czechach w XIV i XV wieku, p. 204.

58 M. Kintzinger, Stadt und Schule, p. $23 \mathrm{ff}$.

59 P. Krafl, Synody a statuta olomoucké diecéze obdobi středověku, Praha 2003, p. 167.

60 Statuta synodalia 1413, in: ibidem, p. 194.

${ }^{61}$ Multi errores oriuntur a mulieribus habentibus libros theologycos theutunicales de latino in theutunicum translatos.
} 
of interrogating Poles returning from Bohemia and controlling the circulation of books. The issue of spreading and copying Hussite texts in Poland appeared in the synodal statutes of 1420 for the first time. The remedia contra hereticos orders that bishops or their clerks, during canonical visitations, should control the books possessed by parochial priests ad aliqua suspecta sint in eisdem libris inserta. ${ }^{62}$ Point three prohibits unknown preachers to preach in parishes, while point four of this document prohibits employing people who returned from Bohemia as teachers. ${ }^{63}$ Hussite matters were discussed also during the synod called by Archbishop Wojciech Jastrzębiec (1432-1436) and Jakub of Korzkwia, Bishop of Płock, on 01 April $1425 .{ }^{64}$ Anti-Hussite articles were published also in synodal statutes of the dioceses Poznań and Cracow. ${ }^{65}$ Synod provisions were a response to numerous cases of Hussite texts copied not only by school teachers but also by parish priests, townsmen and nobles. ${ }^{66}$

A number of sources show that the Hussite texts were copied and translated into Polish by parochial priest, teachers, and scholars. We have evidence from the acts of Church courts of Poznań and Gniezno. ${ }^{67}$ Czech Hussite texts reached Poland, and were copied and disseminated here, often via schools. ${ }^{68}$ The Inquisition also fought with teachers distributing Hussite texts, among others in Zbąszyń. ${ }^{69}$ Sources show that the scale of sympathy for Hussite values among school teachers was significant. ${ }^{70}$

In Polish dioceses, there are more examples of laws concerning changes in education. At the beginning of the $15^{\text {th }}$ century, the Church authorities in the diocese of Cracow attributed low ethical and intellectual standards of the clergy to the multiplication of schools deprived of suitable teachers in small towns and villages. ${ }^{71}$ In 1456 , the synod of Gniezno ordered all the elder students of parochial schools to move to the University of Cracow or to a cathedral/ collegiate school, which employed bachelors or masters of art. ${ }^{72}$ A parochial school should

62 Remedia contra haereticos, in: Statuty synodalne wieluńsko-kaliskie Mikołaja Trąby z r. 1420, ed. B. Ulanowski, J. Fijałek, A. Vetulani, Kraków 1915-1951, p. 96. See: E. Potkowski, Książka i pismo w średniowieczu: studia $z$ dziejów kultury piśmiennej i komunikacji społecznej, Pułtusk 2006, p. 69; J. Drabina, Episkopat polski wobec husytyzmu, in: Polskie echa husytyzmu. Materiały z konferencji naukowej Kłodzko, 27-28 września 1996, ed. S. Bylina, R. Gładkiewicz, Warszawa 1999, p. 62-81.

63 Remedia contra haereticos, p. 95-96. See: P. Kras, Husyci w piętnastowiecznej Polsce, Lublin 1998, p. 94.

64 L. Zygner, Działalność synodalna arcybiskupa Wojciecha Jastrzębca. Próba retrospekcji i reinterpretacji, „Studia Mazowieckie", 10 (2015), z. 3, p. 65 ff.

65 Statuta synodalia Andrae episcopi Posnaniensis saeculo XVmo confecta, ed. U. Heyzman, in: Starodawne Prawa Polskiego Pomniki, vol. 5: Supplementum, p. XI-XXXV; Statuta Alberti Jastrzębiec Episcopi Cracoviensis, Cracoviae anno 1423 edita, ed. U. Heyzmann, in: ibidem, pp. 63-86.

${ }^{66}$ E. Potkowski, Książka i pismo, p. 70; idem, Książka rękopiśmienna w kulturze Polski średniowiecznej, Warszawa 1984 , p. 215.

67 Acta capitulorum nec non iudiciorum ecclesiasticorum selecta, ed. B. Ulanowski (further: $A C I$ ), vol. 2: Acta iudiciorum ecclesiasticorum diocesum gneznensis et poznaniensis (1403-1530), Kraków 1902, no 524.

68 W. Iwańczak, Polskie badania nad wplywami husyckimi w Polsce, in: Polskie echa husytyzmu, pp. 20-31.

69 P. Kras, Inkwizycja papieska $w$ walce z husytyzmem na ziemiach polskich, in: Polskie echa husytyzmu, p. 105106.

70 See: Ruch husycki w Polsce. Wybór tekstów źródtowych (do r. 1454), ed. R. Heck, E. Maleczyńska, Wrocław 1953, passim.

71 Statuty diecezjalne krakowskie z roku 1408, ed. B. Ulanowski, Archiwum Komisji Historycznej PAU, vol. 5, 1889, p. 26.

72 J. Sawicki, Synody archidiecezji gnieźnieńskiej i ich statuty, Warszawa 1950, p. 62; Statuta a sinododi dieocesiani Gneznensi promulgata, ed. B. Ulanowski, in: ACI, vol. I: Acta capitulorum gneznensis, poznaniensis et vladislaviensis (1408-1530), Kraków 1894, No 1860. 
offer education only for younger pupils. Even at the end of 15th century we can see that the Church in Poland was still very suspicious of the Hussite ideology. In 1477 bishop Zbigniew Oleśnicki (1473-1480), commands to check whether scholars, especially from Bohemia, are followers of the heresy. ${ }^{73}$

$$
* * *
$$

Historians maintain that Hussite influences in Poland are difficult to evaluate. Stanisław Bylina is doubtful about the extent to which the Hussites impacted Poland. ${ }^{74}$ As Paweł Kras underlines, recent studies of historical sources show the limited number of Polish advocates of Hussite ideas and ephemeral functioning of their main centers in Great Poland and Cuiavia. ${ }^{75}$ After Hus's condemnation at Constance, the Polish clergy took steps to stop the penetration of Hussite ideas by means of interrogating Poles returning from Bohemia and controlling the circulation of books. Hussite matters were dealt with in the synodal legislation of Archbishop Mikołaj Trąba. Some issues were discussed at the synod of Uniejów on 5 August 1414, and then - after Archbishop Trąba's return from the Council in Constance -at Wieluń, January 1420, and Kalisz, May 1420, where complex anti-Hussite regulations, Remedia contra hereticos, were issued. The original synod statutes adopted at that time were a response to the expectations of both the clergy and the faithful concerning Hussite matters. ${ }^{76}$ Special attention was paid to the problem of popularization and copying of Hussite texts.

Sympathy for Hussitism, which we can observe among not only some clergy but also many teachers and students, resulted from the religious revival and Hussites' closeness to people notably in linguistic sense - Hussite preachers used the vernacular. Literature developed in national languages, and heretical books were often rewritten in schools. ${ }^{77}$ Many Hussite sympathizers in Poland received their education in Prague. It is not surprising that they were eager to teach reading in Polish and Czech.

Stanisław Bylina emphasizes that Hussitism, as a radical reformation movement of Christianity, caused a great upsurge in religious worship, involvement of the faithful in religious life, and an increase in its quality. ${ }^{78}$ In villages and small towns in the Czech Kingdom and Poland, schooling could only cover a small percentage of children and young people, despite the mass presence of schools. In the 15th century, authorities of Polish dioceses, in order to ensure a higher level of parish schools, set requirements for teachers in schools and opposed an excessive number of pupils. In the statutes of that time it can be read that small boys would be accepted to be taught "customs and writing" and the teacher

\footnotetext{
73 Statuta synodalia dioecesis wladislaviensis et Pomeraniensis, ed. M. Chodyński, Varsaviae 1890, p. 20-23.

74 S. Bylina, Oddźwięki husytyzmu w Królestwie Polskim, in: idem, Hussitica. Studia, Warszawa 2007, pp. 163-180 .

75 P. Kras, Polish Hussitism - An Attempt at Evaluating the scale of the phenomenon, in: Christianity in East Central Europe. Late Middle Ages. Proceedings of the Comission Interlationale d'Histoirie Ecclésiastique Comparée, Lublin 1996, part 2, ed. J. Kłoczowski, P. Kras, W. Polak, Lublin 1999, p. 232.

76 Ibidem, p. 223-229.

77 P. Kras, Husyci w piętnastowiecznej Polsce, p. 74 ff.

78 S. Bylina, Religijność późnego średniowiecza. Chrześcijaństwo a kultura tradycyjna w Europie środkowo-wschodniej w XIV-XV w. Warszawa 2009, p. 11.
} 
was obliged to "teach the sons of parishioners customs, virtues and knowledge." knowledge, as in all Europe at that time, in rural parish schools one could learn reading, writing, church singing and the basics of the liturgical calendar as well as basic prayers in Latin. In municipal schools, the level of teaching was higher, and Latin was more important. ${ }^{80}$

In some connection with Hussitism, there remain decisions about the dangers of women possessing and reading theological texts translated from Latin to German, made during the synod sermon delivered in 1427 in Elbląg. ${ }^{81}$

\section{Bibliography}

\section{Sources}

Acta capitulorum generalium Ordinis Praedicatorum, vol. 1: Ab anno 1220 usque ad annum 1303, ed. A. Frühwirth, B.M. Reichert, Romae 1898.

Acta capitulorum nec non iudiciorum ecclesiasticorum selecta, ed. B. Ulanowski, vol. 1-2, Kraków 1894-1902.

Aenae Silvii Historia Bohemica - Enea Silvio Historie Česká, ed. D. Martínkova, A. Hadravová, J. Matl, Praha 1998.

Bullarium diplomatum et privilegiorum sanctorum romanorum pontificium, ed. A. Tomasseti, vol. 4, Roma 1859.

Collectio canonum in V libris (lib. I-III), cura et studio M. Fornasari, Turnholti 1970.

Corpus Juris Canonici, ed. E. Friedberg, Bd. 2, Leipzig 1881.

Dokumenty soborów powszechnych, vol. 2-3, ed. A. Baron, H. Pietras SJ, Kraków 2002-2007. Jan Długosz, Liber Beneficiorum Diocesis Cracoviensis, vol. 1-3, ed. A. Przeździecki, Kraków 1863-1864.

Monumenta Germaniae Historica, Leges sectio II: Capitularia regum Francorum, Bd. 1, ed. A. Boretius, Hannoverae 1883.

Monumenta Germaniae Historica, Concilia aevi Karolini, ed. A. Werminghoff, Bd. 2, Hannoverae-Lipsiae 1906.

Patrologiae cursus completus, sive bibliotheca universalis, integra, uniformis, commoda, oeconomica, omnium ss. patrum, doctorum, scriptorumque ecclesiasticorum, sive latinorum, sive graecorum, qui ab aevo Apostolico ad tempora Innocenti III (anno 1216) pro latinis ex concilii florentini (ann. 1439) pro graecis floruverunt, accurante J.-P. Migne, v. I-CCXXI, Paris 1841-1881.

Pražské synody a koncily předhusitské doby, ed. J.V. Polc, Z. Hledíková, Praha 2002.

Ruch husycki w Polsce. Wybór tekstów źródtowych (do r. 1454), ed. R. Heck, E. Maleczyńska, Wrocław 1953.

Sawicki J., Synody archidiecezji gnieźnieńskiej i ich statuty, Warszawa 1950.

Statuta a sinododi dieocesiani Gneznensi promulgata, ed. B. Ulanowski, in: Acta capitulorum nec non iudiciorum ecclesiasticorum selecta, ed. B. Ulanowski, vol. 1: Acta capitulorum gneznensis, poznaniensis et vladislaviensis (1408-1530), Cracoviae 1894, No 1860.

\footnotetext{
79 Ordinationes sub regimene Petri de Bnin, episcopi, anno 1487 editae, in: Statuta synodalia dioecesis Wladislaviensis et Pomeraniae, ed. Z. Chodyński, Warszawa 1880, p. 25.

${ }^{80}$ K. Ratajczak, Szkolnictwo w Wielkopolsce, p. 214 ff.

81 E. Potkowski, Książka i pismo, p. 69.
} 
Statuta Alberti Jastrzębiec Episcopi Cracoviensis, Cracoviae anno 1423 edita, ed. U. Heyzmann, in: Starodawne Prawa Polskiego Pomniki, vol. 5, Kraków 1875, pp. 63-86.

Statuta synodalia Andrae episcopi Posnaniensis saeculo XVmo confecta, ed. U. Heyzman, in: Starodawne Prawa Polskiego Pomniki, vol. 5: Supplementum, Kraków 1875, pp. XI-XXXV.

Statuta synodalia dioecesis wladislaviensis et Pomeraniensis, ed. M. Chodyński, Warszawa 1890.

Statuty diecezjalne krakowskie z roku 1408, ed. B. Ulanowski, Kraków 1889.

Statuty synodalne wieluńsko-kaliskie Mikołaja Trąby z r. 1420, ed. B. Ulanowski, J. Fijałek, A. Vetulani, Kraków 1915-1951.

\section{Literature}

Austtin G., Shaping Church Law Around the Year 1000. The Decretum of Burchard of Worms, Farnham-Burlington 2009.

Boyle L.E., Notes on the Education of the "Fratres communes" in the Dominican Order in the Thirteenth Century, in: Xenia medii aevi historiam illustrantia oblata Thomae Kaeppeli, ed. R. Creytens, P. Künzle, vol. 1, Roma 1978, p. 249-267.

Bylina S., Oddźwięki husytyzmu w Królestwie Polskim, in: idem, Hussitica. Studia, Warszawa 2007, p. 163-180.

Bylina S., Podróż husytów do Bazylei, Warszawa 2013.

Bylina S., Religijność późnego średniowiecza. Chrześcijaństwo a kultura tradycyjna w Europie środkowo-wschodniej w XIV-XV w., Warszawa 2009.

Cobban A.B., The Medieval Universities. Their Development and Organization, Oxford 1975.

Čornej P., Svétla a stíny husitství (události - osobnosti - texty - traduce). Výbor z úvah a studií, Praha 2011.

Doležalová E., Hledíková Z., Die Erforschung der Entstehung und Ausprängung des Pfarreinetzes bis zum Beginn der hussitischen Revolution in der tschechischen Geschichtswissenschaft, in: Pfarrein im Mittelalter, Deutschland, Polen, Tschechen und Ungarn im Vergleich, hrsg. N. Kruppa, Göttingen 2008, pp. 83-98.

Drabina J., Episkopat polski wobec husytyzmu, in: Polskie echa husytyzmu. Materiaty z konferencji naukowej Kłodzko, 27-28 września 1996, ed. S. Bylina, R. Gładkiewicz, Warszawa 1999, pp. 62-81.

Duggan A.J., Conciliar Law 1123-1215. The Legislation of the Four Lateran Councils, in: The History of Medieval Canon Law in the Classical Period, 1140-1234. From Gratian to the Decretals of Pope Gregory IX, ed. W. Hartmann, K. Pennington, Washington 2008, pp. 318-366.

Eberl I., Cystersi. Historia zakonu europejskiego, transl. P. Włodyga, Kraków 2011.

Heiler F., Schulen in der Kleiner hochstiftsstädten. Ein Vergleich innerhalb des Hochstifts Erchstädt und mit seinen weltlichen Nachborn (ca. 1400-1600), in: Schullandschaften in Altbayern, Franken und Schwaben. Untersuchungen zur Ausbreitung und Typologie des Bildungswesens in Spätmittelalter und Früher Neuzeit, hrsg. v. H. Flachenecker, R. Kiessling, München 2005, pp. 62-74.

Hinnebusch W.A. OP, The History of the Dominican Order. Intellectual and Cultural Life to 1500, vol. 1-2, New York 1973. 
Iwańczak W., Polskie badania nad wptywami husyckimi w Polsce, in: Polskie echa husytyzmu. Materiały z konferencji naukowej Kłodzko, 27-28 września 1996, ed. S. Bylina, R. Gładkiewicz, Warszawa 1999, pp. 20-31.

Jakob R., Spätmittelalterliche Schullandschaften in Franken und in Bayern 1250-1520. Ein Vergleich anhand ausgewählter Perspektiven und Beispiele, in: Schullandschaften in Altbayern, Franken und Schwaben. Untersuchungen zur Ausbreitung und Typologie des Bildungswesens in Spätmittelalter und Früher Neuzeit, hrsg. v. H. Flachenecker, R. Kiessling, München 2005, pp. 157-182.

Johnson J., A Collection of the Laws and Canons of the Church in England, vol. 1, Oxford 1850.

Kaczmarek K., Studia uniwersyteckie cystersów z ziem polskich w okresie średniowiecza, Poznań 2005.

Kaczmarek K., Szkoły i studia polskich dominikanów w okresie średniowiecza, Poznań 2005.

Kintzinger M., Stadt und Schule im hoch- und spätmittelalterlichen Reich. Genese und Perspektiven der mediävistlichen Stadtschulforschung, in: Schullandschaften in Altbayern, Franken und Schwaben. Untersuchungen zur Ausbreitung und Typologie des Bildungswesens im Spätmittelalter und Früher Neuzeit, hrsg. v. H. Flachenecker, R. Kiessling, München 2005, pp. 15-42.

Kitzinger M., A profession but not a Career? Schoolmasters and the Artes in Late Medieval Europe, in: Universities and schooling in Medieval Society, ed. W.J. Courtenay, J. Miethke, Leiden 2000, pp. 167-181.

Kitzinger M., Studens atrium, Rector parochie und Magister scolarum im Reich des 15. Jahrhunderts. Studium und Versorgunschancen der Artisten zwischen Kirche und Gesellschaft, ,Zeitschrift für Historische Forschung“, 26 (1999), pp. 1-43.

Kłoczowski J., Polska Prowincja Dominikańska w średniowieczu i Rzeczypospolitej Obojga (wielu) Narodów, Poznań 2008.

Krafl P., Synody a statuta olomoucké diecéze obdobi středověku, Praha 2003.

Kras P., Husyci w piętnastowiecznej Polsce, Lublin 1998.

Kras P., Inkwizycja papieska w walce z husytyzmem na ziemiach polskich, in: Polskie echa husytyzmu. Materiały z konferencji naukowej Kłodzko, 27-28 września 1996, ed. S. Bylina, R. Gładkiewicz, Warszawa 1999, pp. 88-115.

Kras P., Polish Hussitism - An Attempt at Evaluating the scale of the phenomenon, in: Christianity in East Central Europe. Late Middle Ages. Proceedings of the Comission Internationale d'Histoirie Ecclésiastique Comparée, Lublin 1996, part 2, ed. J. Kłoczowski, P. Kras, W. Polak, Lublin 1999, pp. 232-243.

Maleczyńska K., Zainteresowania czytelnicze mieszczan dolnośląskich okresu Renesansu, Wrocław 1982.

McCormick P.J., History of Education, New York 1957.

Mordek H., Kirchenrecht und reform im Frankenreich. Die Collectio vetus Gallica. Die Älteste systematische kanonessammlung des Fränkischen Gallien. Studien und edition, Berlin-New York 1975.

Morris C., The Discovery of the Individual 1050-1200, Toronto 1991.

Mulchahey M.M., "First the Bow is Bent in Study...". Dominican Education before 1350, Toronto 1998. 
Nikodem J., Polska i Litwa wobec husyckich Czech w latach 1420-1433. Studium o polityce dynastycznej Władysława Jagiełty i Witolda Kiejstutowicza, Poznań 2004.

Nodl B.M., Klerici, rektoři a scholárové, in: Pater familia. Sbornik přispěvkủ kživotnímu jubileu Prof. Dr. Ivana Hlaváčka, ed. J. Hrdina, Praha 2002, pp. 299-311.

Pfarrein im Mittelalter, Deutschland, Polen, Tschechen und Ungarn im Vergleich, Hrsg. N. Kruppa, Göttingen 2008.

Plisiecki P., The Parochial Network and the Tithes System in the Medieval Diocese Cracow, in: Pfarrein im Mittelalter, Deutschland, Polen, Tschechen und Ungarn im Vergleich, hrsg. N. Kruppa, Göttingen 2008, pp. 223-234.

Potkowski E., Książa i pismo w średniowieczu: studia z dziejów kultury piśmiennej i komunikacji społecznej, Pułtusk 2006.

Potkowski E., Książka rękopiśmienna w kulturze Polski średniowiecznej, Warszawa 1984.

Rashdall H., The Universities of Europe in the Middle Ages, vol. 2, part 1: Italy, Spain, France, Germany, Scotland etc., Cambridge 2010.

Ratajczak K., Szkolnictwo w Wielkopolsce na tle sasiadów w okresie średniowiecza, Poznań 2017.

Riché P., Edukacja i kultura w Europie Zachodniej (VI-VIII w.), transl. M. Radożycka-Paoletti, Warszawa 1995.

Roest B., A history of Franciscan Education (c.1210-1517), Leiden-Boston-Köln 2000.

Rolker Ch., Canon Law and the Letters of Ivo of Chartes, New York 2010.

Sarnowsky J., Die artes im Lehrplan der Universitäten, in: Artes im Mittelalter, Hrsg. v. U. Schaefer, Berlin 1999, pp. 68-82.

Šmahel F., Causa non grata: Premature Reformation in Hussite Bohemia, in: Christianity in East Central Europe. Late Middle Ages. Proceedings of the Comission Interlationale d'Histoirie Ecclesiastique Compere, Lublin 1996, part 2, ed. J. Kłoczowski, P. Kras, W. Polak, Lublin 1999, pp. 224-231.

Šmahel F., Husitská revoluce, v. 3: Kronika válečných let, Praha 1993.

Šmahel F., Piśmienność warstw ludowych w Czechach $w$ XIV i XV wieku, in: Kultura elitarna a kultura masowa w Polsce późnego średniowiecza, ed. B. Geremek, Wrocław 1978, pp. 189-205.

Šmahel F., Słowo pisane i mówione w stużbie reformy husyckiej, transl. P. Kras, in: Kultura pisma w średniowieczu. Znane problemy, nowe metody, ed. A. Adamska, P. Kras, Lublin 2013, pp. 175-194.

Stopka K., Szkoła zakonna w Polsce średniowiecznej jako problem badawczy, in: Klasztor w kulturze średniowiecznej Polski, ed. A. Pobóg-Lenartowicz, M. Derwich, Opole 1995, pp. 49-61.

The History of Medieval Canon Law in the Classical Period, 1140-1234: From Gratian to the Decretals of Pope Gregory IX, ed. W. Hartmann, K. Pennington, Washington 2008.

Topfer B., Rola uniwersytetów oksfordzkiego i praskiego w rozwoju koncepcji wczesnoreformacyjnych (koniec XIV-poczatek XV wieku), „Kwartalnik Historyczny”, 89 (1982), z. 1, pp. 3-14.

Van Zijl T.P., Gerard Groote, ascetic and reformer (1340-1384), Washington 1963. 
Wiśniowski E., Uwagi o liczebności wiejskiego szkolnictwa parafialnego w Polsce $i$ w Czechach u schytku średniowiecza, in: Kultura elitarna a kultura masowa w Polsce późnego średniowiecza, ed. B. Geremek, Wrocław 1978, pp. 207-210.

Zdanek M., Szkoły i studia dominikanów krakowskich w średniowieczu, Warszawa 2005.

Zilynská B., Husitské synody v Čechách, 1418-1440. Příspěvek k uloze univerzitních mistrů $v$ husitské církvi a revoluci, Praha 1985.

Zygner L., Działalność synodalna arcybiskupa Wojciecha Jastrzębca. Próba retrospekcji i reinterpretacji, „Studia Mazowieckie”, 10 (2015), z. 3, pp. 59-82. 